\begin{tabular}{c|c|c}
\hline \hline Vol. 30(2): 1-6, 2020 & BOLETIM DO LABORATÓRIO DE HIDROBIOLOGIA & $\begin{array}{c}\text { Submitted on 03/25/2020 } \\
\text { Accepted on 05/29/2020 } \\
\text { Published on 07/22/2020 }\end{array}$ \\
\hline \hline
\end{tabular}

SHORT COMMUNICATION

\title{
WRONG WAY HOME: AN INFANT SOUTHERN ELEPHANT SEAL (Mirounga leonina) ARRIVAL ON SOUTHEASTERN BRAZILIAN BEACHES
}

Salvatore Siciliano ${ }^{1,2 *(D)}$, Paula Baldassin ${ }^{3}$ (D), Rachel Ann Hauser-Davis ${ }^{4}$ (D), Luis Felipe S. P. Mayorga ${ }^{5}$ (D), Sérgio C. Moreira ${ }^{(D D}$, Tatiane B. Vieira ${ }^{7}$, Ivan A. Ribeiro ${ }^{7}$, Renata F. Buffa ${ }^{7}$ (D), Carlos Eduardo S. de Amorim $^{2}$ (D)

${ }^{1}$ Laboratório de Biodiversidade, Instituto Oswaldo Cruz/Fiocruz, Rio de Janeiro, RJ Brazil

${ }^{2}$ Grupo de Estudos de Mamíferos Marinhos da Região dos Lagos (GEMM-Lagos), Praia Seca, Araruama, RJ Brazil

${ }^{3}$ BW Consultoria Veterinária, Praia Seca, Araruama, RJ Brazil

${ }^{4}$ Laboratório de Avaliação e Promoção da Saúde Ambiental, Instituto Oswaldo Cruz/Fiocruz, Rio de Janeiro, RJ Brazil

${ }^{5}$ Instituto de Pesquisa e Reabilitação de Animais Marinhos (IPRAM), Cariacica, ES, Brazil

${ }^{6}$ Setor de Mastozoologia, Departamento de Vertebrados, Museu Nacional/UFRJ, Rio de Janeiro, RJ Brazil

${ }^{7}$ Braço Social - Consultoria Socioambiental e Cultural, Açu, São João da Barra, RJ Brazil

*Corresponding author e-mail: gemmlagos@gmail.com

\begin{tabular}{l} 
RESUMO \\
É reportada a ocorrência recente de um infante de elefante-marinho (Mirounga leonina) na costa do \\
estado do Rio de Janeiro com um intervalo aproximado de um mês entre as avistagens do mesmo \\
indivíduo. A comparação das fotografias obtidas em ambos os registros permitiu a comparação e \\
confirmação. Em adição, se discute a presença de infantes na costa brasileira, que totalizam oito \\
casos, mas que não apontam uma sazonalidade marcada, mas uma tendência aos registros serem \\
reportados em junho, seguido por outubro e novembro. Como o presente registro se deu em janeiro, \\
pico do verão, fatores climáticos de larga escala podem estar atuando para deslocar alguns indivíduos \\
muito ao longe das suas colônias. \\
Palavras-chave: Mirounga leonina, movimentos, vagante, Atlântico Sul. \\
ABSTRACT \\
Records of southern elephant seals (Mirounga leonina) as vagrants along the SE Brazilian coast \\
date back the late 50's and have been relatively common over the last decades. These large marine \\
mammals usually call much attention when they arrive on tropical beaches worldwide and are \\
generally treated as 'occasional visitors' and 'vagrants'. This note reports on sightings of a young \\
elephant seal along SE Brazil in the summer and autumn of 2020. We also reviewed records in both \\
the literature and open sources, totaling eight records of infant southern elephant seals known since \\
the late 70's along the Brazilian coast. It was noted that the arrival of an infant in February of 2020 \\
is coincident with a previous cyclonic activity off the SE and NE Brazilian coast. The connection \\
of such unlikely records of pinnipeds on tropical beaches and extreme weather events associated to \\
ocean currents should be better evaluated in the context of climatic change \\
Keywords: Mirounga leonina, erratic movements, vagrant, South Atlantic. \\
\hline
\end{tabular}

Records of southern elephant seals (Mirounga leonina) as vagrants along the SE Brazilian coast date back the late 50's (Carvalho, 1975) and have been relatively common over the last decades (Moura et al. 2010; 2011; Mayorga et al., 2016). Most of these observations comprised by subadults or adults, some of them apparently healthy, resting on beaches, and resighted during several weeks at the same spot (Magalhães et al., 2003; Mayorga et al., 2017). These large marine mammals usually call much attention on tropical and subtropical beaches worldwide and are generally treated as 'occasional visitors' and 'vagrants' (Castello \& Pinedo, 1977; Pinedo, 1990; Pinedo et al.; 1992; Simões-Lopes et al. 1995; Shaughnessy et al. 2012; Webster et al., 2016). As most of the pinniped records on the coast of south-eastern Brazil, including M. leonina, are largely concentrated during winter months, from June to September (Moura \& Siciliano, 2007; Moura et al. 2010), the general public often 'perceives' 
and associates their arrival to cold fronts and cooler temperatures. But what to say when such a pinniped record occurs in the peak of summer? In this context, the purpose of this note is to report on sightings of young elephant seals, smaller than 2,0 m long, on beaches along SE Brazil, namely at Açu, located in São João da Barra, on the northern coast of Rio de Janeiro and, subsequently, in the city of Rio de Janeiro, Brazil.

Early in the morning of 05 February 2020, a team of beach patrols found the resting pinniped on the sand of Açu, in São João da Barra, on the northern coast of the state of Rio de Janeiro. The specimen was identified based on characters described by Jefferson et al. (2008). The young elephant seal seemed to be in apparent good health, simply laying on the beach and warming up after a long journey out in the sea. It was reported that it suddenly returned to the sea after the arrival of the beach patrols, probably stressed by the presence of dogs (Figure 1).

Approximately one month later, on 3 March 2020, the arrival of an infant elephant seal at 10:30 AM on the beach of Barra da Tijuca, Rio de Janeiro was reported by one the authors (C.E.S. Amorim). The specimen was a male, $1,30 \mathrm{~m}$ long, and rested all day at the same spot (Figure 2). At night it went out back to sea. It defecated on the sand. The body had numerous barnacles attached, very probably Conchoderma auritum, as previously observed on specimens at Arraial do Cabo and Vila Velha, SE Brazil (Magalhães et al. 2003; Mayorga et al. 2017) and in South Africa (Best, 1971).

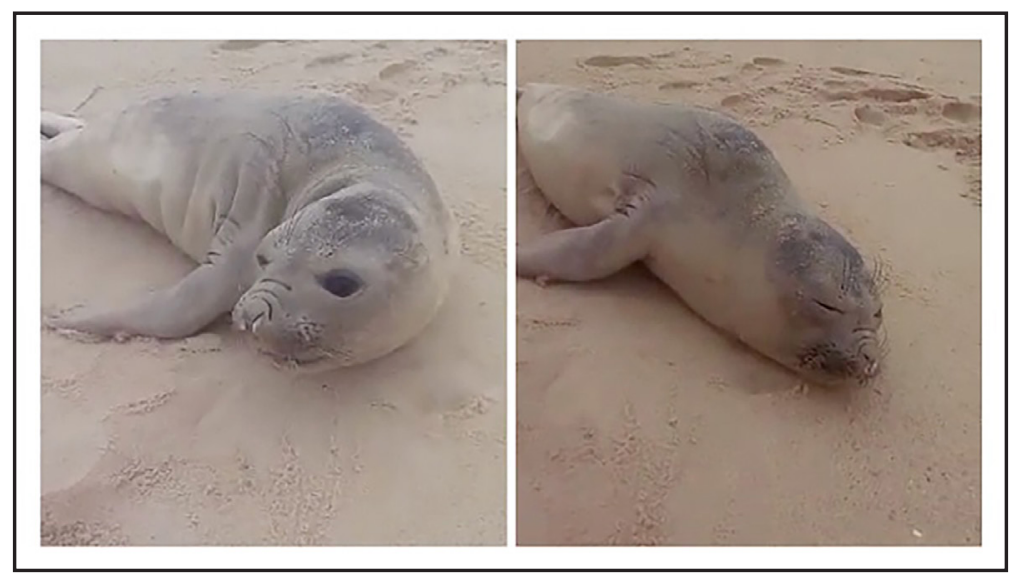

Figure 1. Young elephant seal reported at Açu, a beach located in São João da Barra, on the northern coast of the state of Rio de Janeiro, Brazil. Photos are stills taken from a video made by the beach patrolling team (Photos by I.A. Ribeiro and R.F. Buffa).

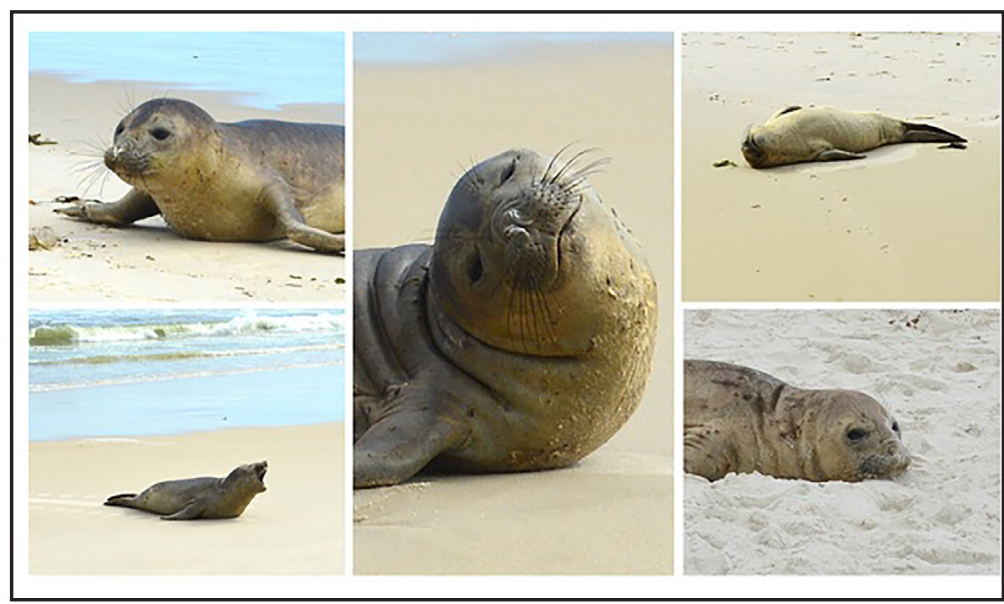

Figure 2. Young elephant seal reported at Barra da Tijuca, a beach located in the city of Rio de Janeiro, in the state of Rio de Janeiro, Brazil. Photographs by R. A. Hauser-Davis. 
Both sightings seem to concern the same individual, as an identical, almost horizontal, flesh wound located slightly above the right flipper was observed in both animals, even though they were sighted one month apart (Figure 3).

Considering these quite unusual sightings and to obtain a better understanding of data available on infant southern elephant seals wandering along the coast of Brazil, we also reviewed records in both the literature and open sources. A total of eight records of infant southern elephant seals are known since the late 70's, when beach monitoring for marine mammals began in southern Brazil, and subsequently in the 80's along the south-eastern coast (Table 1; Figure 4).
In general, the low number of records may be due to a variety of reasons, and we can only speculate that the chance of survival of newborns and infants during such a long journey after weaning in their Patagonian calving grounds (Falabella \& Campagna, 1999 ) is quite small. For straggler pinnipeds, diseases (Bastida et al. 1999; Amorim et al. 2014) and predation by large sharks have been previously reported (Rosas et al. 1992), while other threats, such as fisheries interactions (Machado et al. 2015) and human aggression, both on land and sea (Drehmer et al. 1998; Oliveira et al. 2001; Siciliano et al., 2016) are also noteworthy, which greatly reduce the chances of surviving vagrancy periods.

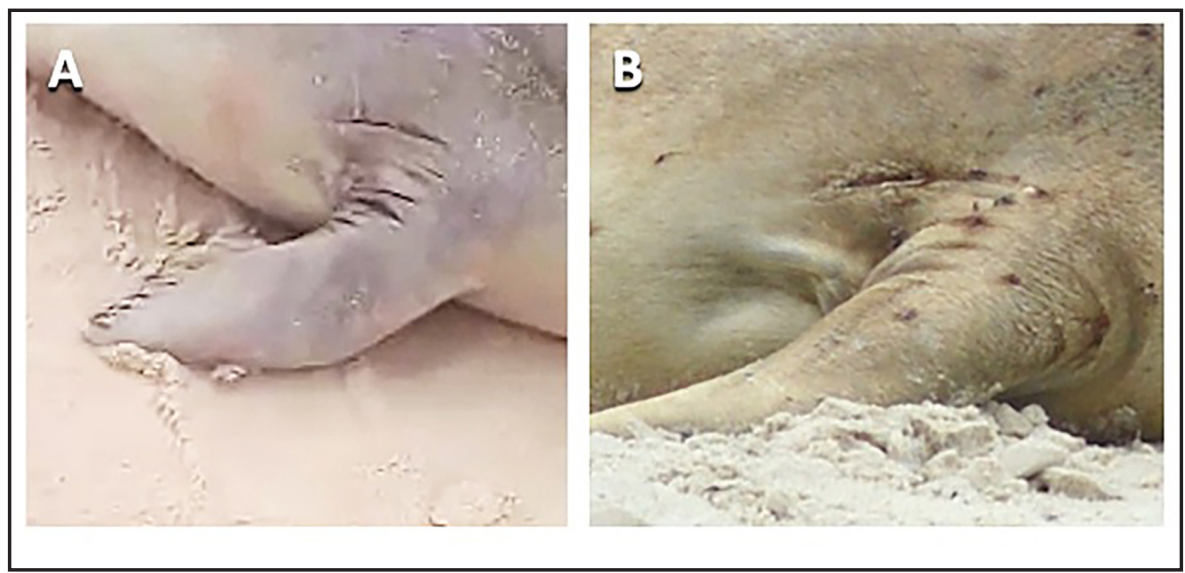

Figure 3. Almost horizontal, flesh wound located slightly above the right flipper in (A) the Açu specimen and (B) the Barra da Tijuca specimen. (A) is a still taken from a video made by the beach patrol team, (B) by R. A. Hauser-Davis.

Table 1. Records concerning sightings of infant southern elephant seals in Brazil.

\begin{tabular}{|c|c|c|c|c|c|}
\hline $\mathrm{N}^{\mathrm{o}}$ & Locality of occurrence & Date & $\operatorname{Sex}$ & BL (cm) & Source \\
\hline 1 & Praia do Cassino, Rio Grande, RS & 15 June 1981 & M & 190 & Pinedo, 1990 \\
\hline 2 & São José do Norte, RS & 17 October 1985 & $?$ & 150 & Pinedo, 1990 \\
\hline 3 & São Francisco do Sul, SC & 03 June 1994 & $?$ & 150 & $\begin{array}{c}\text { Caseca-Santos and Soto, } \\
1998\end{array}$ \\
\hline 4 & Praia do Cassino, Rio Grande, RS & December 2000 & $\mathrm{~F}$ & 190 & Silva, 2004 \\
\hline 5 & $\begin{array}{c}\text { Praia do Segundo Distrito Naval, } \\
\text { Barra, Salvador, BA }\end{array}$ & 11 February 2002 & M & 137 & Bastos et al. 2006 \\
\hline 6 & Praia dos Padres, Aracruz, ES & 05 November 2013 & M & 156 & Portal G1 and Portal 27 \\
\hline 7 & Praia do Açu, São João da Barra, RJ & 05 February 2020 & $?$ & $\sim 160$ & Present record \\
\hline 8 & Praia da Barra da Tijuca, RJ & 03 March 2020 & M & 130 & Present record \\
\hline
\end{tabular}




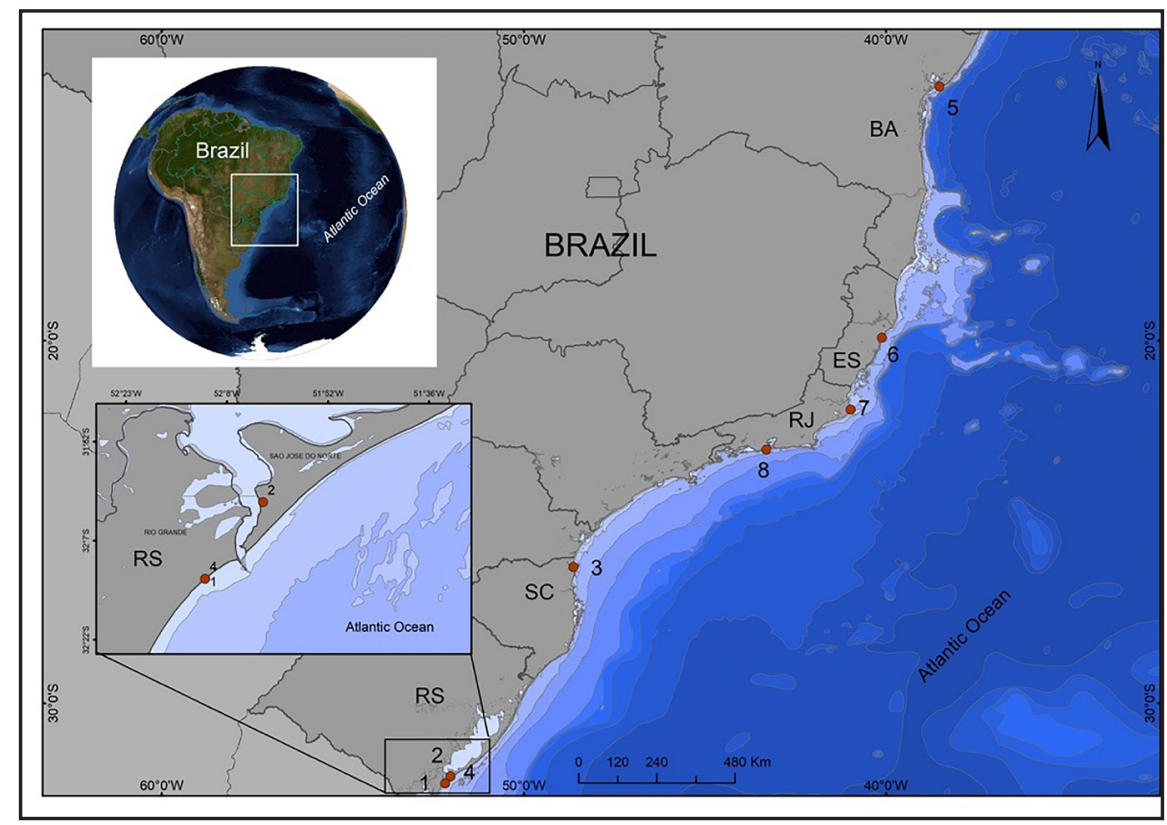

Figure 4. Map indicating records of young elephant seals, smaller than 2,0 $\mathrm{m}$ long, on beaches along the Brazilian coast. Occurrences \#7 and \#8 point out the records along SE Brazil that are treated in detail in this note.

Regarding the period of its arrival, the present observation occurred during the peak of summer, coincident with a Salvador (Bahia) record. Other reported observations of infant elephant seals in Brazil were in June $(n=2)$, October $(n=1)$, November $(n=1)$ and December $(n=1)$. This agrees to a certain extent with the review provided by Moura et al. (2010), which indicates June (24\% out of 45 records) as the month comprising the highest number of specimens of elephant seals observed along the Brazilian coast, followed by August (20\%), July $(17,8 \%)$ and November $(11,1 \%)$. However, the arrival in February of 2020 is coincident with a previous cyclonic activity off the SE and NE Brazilian coast (Brazilian Marine Meteorological Service, 2020a, b), in the form of a subtropical storm named Kurumí ("boy", in the indigenous Tupi-Guarani language) where strong rainfall associated with rough seas and intense wave undulations prevailed, playing a role in many Brazilian floods and mudslides.

The connection of such unlikely records of pinnipeds on tropical beaches and extreme weather events associated to ocean currents should be better evaluated in the context of climatic change, as several studies have linked climate alterations to higher sea surface temperature, decreased ice cover and altered ocean circulation, salinity, rainfall patterns, and climate patterns, among many others (Learmonth et al., 2006; Silber et al., 2017), modifying oceanic currents worldwide (NASA, 2020; Caesar et al., 2018; Thornalley et al., 2018). For example, an increase in kinetic energy since the 1990s has been observed in about $76 \%$ of oceans at 2,000 $\mathrm{m}$ in depth, and, overall, ocean current speeds have risen by about 5\% per decade since the early 1990s (Voosen, 2020). These, and other climate change effects, have led to significant changes in marine mammal geographical distributions, including pinnipeds (Kelly, 2001; Learmonth et al., 2006). Whether such records of infant elephant seals are erratic movements triggered by large scale ocean circulation or a matter of casualty, these accounts deserve reporting for a future assessment.

Note added in proof: Following the record of the infant elephant seal in Barra da Tijuca, Rio de Janeiro, on 3 March 2020, this individual was resighted, resting on beaches bordering the east coast of the state, in this way: on 12 April 2020 in Ponta Negra (Maricá), on 5 May 2020 in Praia Grande (Arraial do Cabo) and on 21 May 2020 in Praia de Geribá, Armação dos Búzios. All these records were verified in loco by at least one of the authors.

\section{ACKNOWLEDGMENTS}

We thank life savers and bathers from Barra da Tijuca, Rio de Janeiro, for their information on the specimen sighted at that spot. S. Siciliano is 
supported by CNPq (Produtividade em Pesquisa: 306076/2019-5) and INOVA Fiocruz. Many thanks to the reviewers. J. F. de Moura and L. R. de Oliveira, for their insightful comments on the note.

\section{REFERENCES}

Amorim, D.B., Casagrande, R.A., Alievi, M.M., Wouters, F., Oliveira, L.G.S., Driemeier, D., Tavares, M., Ikuta, C.Y., Telles, E.O. \& Ferreira-Neto, J.S. 2014. Mycobacterium pinnipedii in a stranded South American sea lion (Otaria byronia) in Brazil. Journal of Wildlife Diseases 50: 419-422. https://doi. org/10.7589/2013-05-124

Bastida R., Loureiro, J., Quse, V., Bernardelli, A., Rodríguez, D. \& Costa, E. 1999. Tuberculosis in a wild Subantarctic Fur Seal from Argentina. Journal of Wildlife Diseases 35: 796-798. https://doi. org/10.7589/0090-3558-35.4.796

Bastos, B.L., Norberto, G.O., Mais-Nogueira, R. \& Guimarães, J.E. 2006. Avaliação hematológica e dosagem bioquímica de ALT, AST e creatinina em elefante-marinho-do-sul, Mirounga leonina (Linnaeus, 1758), encontrado no litoral de Salvador, Bahia. Braz. J. Vet. Res. Anim. Sci., 43(1): 18-23. https://pesquisa.bvsalud.org/portal/resource/pt/lil453736

Best. P.B. 1971. Stalked barnacles Conchoderma auritum on an elephant seal: Occurrence of elephant seals on South African Coast. Zoologica Africana 6:2, 181-185. https://doi.org/10.1080/00445096.19 71.11447410

Brazilian Marine Meteorological Service. 2020. WARNINGS AND FORECASTS- SUBTROPICAL STORM KURUMI. Marine Meteorological Service. 24 Jan 2020. Available at: https://www.marinha. mil.br/chm/dados-do-smm/warnings-and-forecasts/ warnings. Retrieved 26 Feb 2020.

Brazilian Marine Meteorological Service. 2020. SPECIAL WARNING - SUBTROPICAL DEPRESSION “KURUMI”. Centro de Hidrografia da Marinha: MARINHA DO BRASIL. January 25, 2020. Available at: https://www.marinha.mil.br/chm/ dados-do-smm/warnings-and-forecasts/warnings. Retrieved 26 Feb 2020.

Caesar, L., Rahmstorf, S., Robinson, A., Feulner, G. \& Saba, V. 2018. Observed fingerprint of a weakening Atlantic Ocean overturning circulation. Nature 556(7700), 191-196. https:// doi.org/10.1038/s41586-018-0006-5

Carvalho, C. T. 1975. Ocorrência de mamíferos marinhos no Brasil. Boletim Técnico do Instituto Florestal 16:13-32

Castello, H.P. \& Pinedo, M.C. 1977. Os visitantes ocasionais de nosso litoral. Natureza em Revista 3: 40-46.

Drehmer, C.J., Ferigolo, J., Borsato, E.S. 1998. Ocorrência de Mirounga leonina Linnaeus (Pinnipedia, Phocidae) no extremo-sul do Brasil: agressão e patologias. Revista Brasileira de Zoologia 15: 1061-1068.

Falabella, V. \& Campagna, C. 1999. Behaviour of southern elephant seal weanlings during the postweaning fast in Patagonia. Mammalia 63: 257

G1 Espírito Santo, 2013. Elefante marinho de $60 \mathrm{~kg}$ é resgatado em praia do ES. http://g1.globo.com/ espirito-santo/noticia/2013/11/elefante-marinho-de60-kg-e-resgatado-em-praia-do-es.html

Jefferson, T.A., Webber, M.A. \& Pitman, R.L. 2008. Marine mammals of the world: a comprehensive guide to their identification. London: Academic Press. 592 pp.

Kelly, B.P. 2001. Climate change and ice breeding pinnipeds. In: Walther GR., Burga C.A., Edwards P.J. (eds) "Fingerprints" of Climate Change. Springer, Boston, MA.

Learmonth, J.A., Macleod, C.D., Santos, M.B., Pierce, G.J., Crick, H.Q.P., Robinson, R.A. 2006. Oceanography and Marine Biology: An Annual Review 44:431-464. doi: 10.1201/9781420006391. ch8

Machado, R., Oliveira, L.R. \&. Montealegre, S.Q. 2015. Incidental catch of South American sea lion in a pair trawl off Southern Brazil. Neotropical Biology and Conservation 10: 43-47.

Magalhães, F.A., Hassel, L.B., Venturotti, A.C. \& Siciliano, S. 2003. Southern Elephant Seals (Mirounga leonina) on the coast of Rio de Janeiro state, Brazil. Latin American Journal of Aquatic Mammals 2(1): 55-56. doi: 10.5597/lajam00032

Mayorga, L.F.S.P., Bhering, R.C.C., Hurtado, R. \& Vanstreels, R.E.T. 2017. Recurrent sightings of a Southern elephant seal (Mirounga leonina) on the southeast coast of Brazil, 2012 - 2017. Latin American Journal of Aquatic Mammals 12(1-2): 53-58. doi: 10.5597/lajam00237 
Mayorga, L.F.S.P., Hurtado, R., Vanstreels, R.E.T., Bhering, R.C.C., Rossi Junior, J.L. 2016. A review of the recent records of pinnipeds (Mammalia, Carnivora) on the coast of Espírito Santo state, Brazil. Check List 12(6). doi: http://dx.doi. org/10.15560/12.6.2015.

Moura, J.F. \& Siciliano, S. 2007. Straggler subAntarctic fur seals (Arctocephalus tropicalis) on the coast of Rio de Janeiro state, Brazil. Latin American Journal of Aquatic Mammals 6: 103-107. doi: 10.5597/lajam00114

Moura, J.F., Di Dario, B.P.S., Lima, L.M. \& Siciliano, S. 2010. Southern Elephant Seals (Mirounga leonina) along the Brazilian coast: review and additional records. Marine Biodiversity Records 3(18): e18. doi: 10.1017/S1755267209991138

Moura, J.F., Di Dario, B.P.S. \& Siciliano, S. 2011. Occurrence of pinnipeds on the coast of Rio de Janeiro state, Brazil. Marine Biodiversity Records 4(27): e27. doi: 10.1017/S1755267211000030

NASA, 2020. Available at: https://climate.nasa. gov/news/2950/arctic-ice-melt-is-changing-oceancurrents/

Oliveira, L.R., Zerbini, A. \& Auricchio, P. 2001. Um possível caso de agressão em Arctocephalus tropicalis (Carnivora, Otariidae) com comentários sobre a conservação de pinípedes no litoral do Brasil. Publicações Avulsas do Instituto Pau Brasil 4: 11-20.

Pinedo, M.C. 1990. Ocorrência de pinípedes na costa brasileira. Garcia d'Orta: Série Zoologia, Lisboa $15,37-48$.

Pinedo, M.C., Rosas, F.C. \& Marmontel, M. 1992. Cetáceos e Pinípedes do Brasil. Uma revisão dos registros e guia para identificação das espécies. Manaus: UNEP/Fundação Universidade do Amazonas.

Portal 27, 2013. Elefante marinho continua tratamento na Bahia. https://www.portal27.com.br/elefantemarinho-continua-tratamento-na-bahia/

Rosas, F.C.W., Capistrano, L.C., Di Beneditto, A.P. \& Ramos, R. 1992. Hydrurga leptonyx recovered from the stomach of a tiger shark captured off the Rio de Janeiro coast, Brazil. Mammalia 56: 153-155.

Shaughnessy, P.D., Kemper, C.M. \& Ling, J.K. 2012. Records of vagrant phocid seals (family Phocidae) in South Australia. Australian Mammalogy 34(2), 155. https://doi.org/10.1071/AM11036

Siciliano, S., Barbosa-Filho, M.L. \& Oliveira, L.R. 2016. Human consumption of a vagrant South American Fur Seal Arctocephalus australis (Carnivora: Otariidae) in Brazil. Journal of Threatened Taxa 8(4), 8728-8731. https://doi. org/10.11609/jott.2525.8.4.8728-8731

Silber, G.K., Lettrich, M.D., Thomas P.O., Baker J.D., Baumgartner, M., Becker E.A., Waples, R.S. 2017. Projecting marine mammal distribution in a changing climate. Frontiers in Marine Science. Frontiers Media S. A. https://doi.org/10.3389/ fmars.2017.00413

Silva, K.G. 2004. Os Pinípedes no Brasil: Ocorrências, Estimativas Populacionais e Conservação. PhD Thesis. Universidade Federal do Rio Grande, Rio Grande, Brazil.

Simões-Lopes, P.C., Drehmer, C.J. \& Ott, P.H. 1995. Nota sobre os Otariidae e Phocidae (Mammalia: Carnivora) da costa norte do Rio Grande do Sul e Santa Catarina, Brasil. Biociências 3(1):173-181.

Thornalley, D.J.R., Oppo, D.W., Ortega, P., Robson, J.I., Brierley, C.M., Davis, R., Keigwin, L.D. 2018. Anomalously weak Labrador Sea convection and Atlantic overturning during the past 150 years. Nature 556(7700), 227-230. https://doi. org/10.1038/s41586-018-0007-4

Voosen, P. 2020. Global warming is speeding up Earth's massive ocean currents. Science, available at: https://www.sciencemag.org/news/2020/02/globalwarming-speeding-earth-s-massive-ocean-currents. doi:10.1126/science.abb1833

Webster, I., Dulau-Drouot, V., Hofmeyr, G. \& Estrade, V. 2016. Records of pinnipeds in the Mascarene Islands, 1996 - 2014. WIO Journal of Marine Science 15 (2): 39-47. 